\title{
CONDYLOPYGE HAWLE ET CORDA, 1847 IN THE PŘÍBRAM-JINCE BASIN (BARRANDIAN AREA, THE CZECH REPUBLIC, AGNOSTIDA)
}

\author{
OLDŘICH FATKA \\ Charles University, Institute of Geology and Palaeontology, Albertov 6, 12843 Praha 2, the Czech Republic; e-mail: \\ fatka@natur.cuni.cz
}

FRANTIŠEK KNÍŽEK

Politických vězňů 127, 26101 Přibram VII, the Czech Republic.

VLADISLAV KOZÁK

K Moravině 11/1689, 190 00, Praha 9 - Libeň, the Czech Republic.

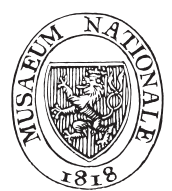

Fatka, O., Knížek, F., Kozák, V. (2015): Condylopyge Hawle et CoRDA, 1847 in the Př́bram-Jince Basin (Barrandian area, the Czech Republic, Agnostida). - Acta Mus. Nat. Pragae, Ser. B, Hist. Nat., 71(1-2): 103-109. Praha. ISSN 1804-6479.

\begin{abstract}
A common occurrence of the widely distributed Cambrian agnostid Condylopyge Hawle et CORDA, 1847 in the Skryje-Týřovice Basin has been well known since the forties of the nineteenth century. In comparison very rare specimens of Condylopyge in the Přibram-Jince Basin were collected as late as in 1992. In this contribution, five disarticulated remains of Condylopyge are reported from three different stratigraphical levels of the Jince Formation in the Príbram-Jince Basin (Barrandian area, the Czech Republic). An internal mould of a small broken cephalon and an external mould of a pygidium collected from lower stratigraphical levels of the Paradoxides (Eccaparadoxides) pusillus Biozone are provisionally assigned to Condylopyge cf. rex (BARRANDE, 1846), as is also a well preserved internal mould of another cephalon originating from lower part of the Onymagnostus hybridus Biozone. The internal mould of the cephalon figured by Valíček and Szabad (2002) from the lower levels of the Acadolenus snajdri Biozone is classified as Condylopyge sp.
\end{abstract}

Cambrian, Agnostida, Condylopyge, stratigraphy, Př́ibram-Jince Basin.

Received May 18, 2015

Issued October, 2015

\section{Introduction}

An abundant Cambrian fauna is known from the marine clastic sediments of the Skryje-Týřovice and Př́bram-Jince basins of the Barrandian area. Due to an abundant occurrence and suitable preservation, trilobites and agnostids have attracted attention since the early $19^{\text {th }}$ century and were studied by numerous researchers (e.g. Schlotheim 1823, Beyrich 1845, Barrande 1846, 1852, 1872; summary see Šnajdr 1958 and Bruthansová et al. 2007).

Several trilobite and agnostid genera established by Hawle and Corda (1847) were based on species described by Barrande (1846). Two of them, Battus rex BARRANDE, 1846 and Battus granulatus BARRANDE, 1846 from Cambrian sediments of the Skryje-Týřovice Basin were designated as type species of two agnostid genera, namely Condylopyge HAWle et CORDA, 1847 and Pleuroctenium HAWle et CORDA, 1847. The very specific cephalic and pygidial morphology of these two genera led Raymond (1913, p. 139) to place them in a separate family Condylopygida (= now Condylopygoidea RAYMOND, 1913) which was later elevated to a superfamilial level by Kobayashi (1962).

According to Shergold et al. (1990) and Shergold and Laurie (1997, p. 332) "the concept of the superfamily Condylopygoidea RAYMOND, 1913 is stable and goes back to the first attempted generic subdivision of Agnostus by Hawle and Corda (1847)". This small superfamily is based only on the Condylopygidae RAYMOND, 1913, which includes Condylopyge and Pleuroctenium, while the position of the recently established Tyragnostus VALÍčEK, 2006 is unresolved; all type species of these genera originate from the Buchava Formation of the Skryje-Týřrovice Basin.

The aim of this contribution is to revise and figure three specimens of Condylopyge from the Prríbram-Jince Basin of the Barrandian area (the Czech Republic; Text-fig. 1) which are housed in institutional collections.

For comparison, three specimens of Condylopyge rex (BARRANDE, 1846), from the Buchava Formation of the Skryje-Týřovice Basins are figured (Text-fig. 2.d-2.f). These specimens come from the collection of the late V. Kordule recently deposited in the National Museum Prague. One of them comes from the Karáskovská rokle - nad chatami locality (Text-fig. 2.d), the other two specimens were collected from Lůmek u Týŕovic (= small quarry near Týřovice; Text-fig. 2.e and Text-fig. 2.f).

\section{Condylopyge in the Barrandian area}

Condylopyge was for a long time known only from the Skryje-Týřrovice Basin (summary Šnajdr 1958, Fatka 2005). Disarticulated exoskeletal remains of this large agnostid are usually quite abundant in fossil associations characterizing the middle and higher stratigraphical levels of the Buchava Formation (Šnajdr 1958). It commonly occurs together with 

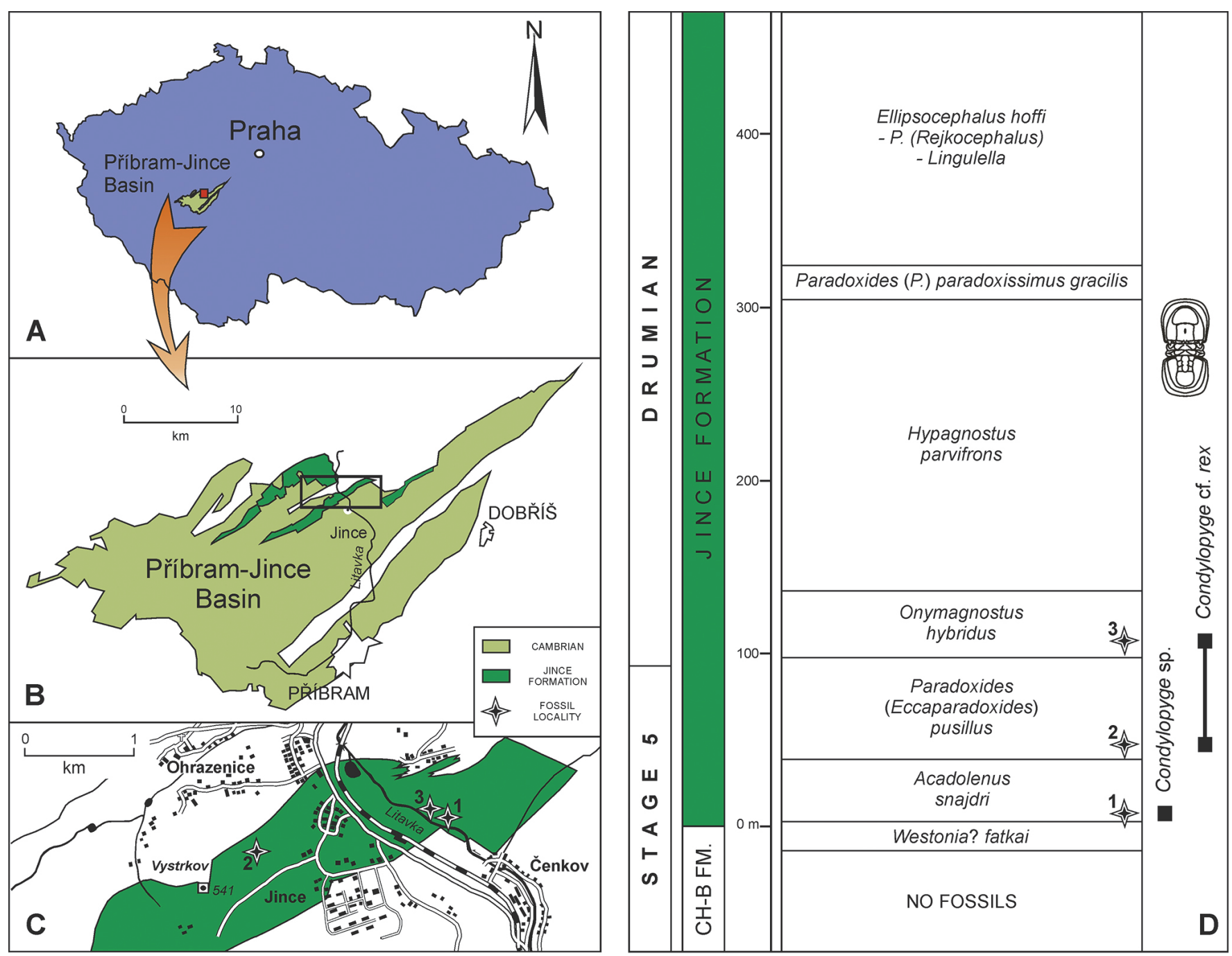

Text-fig. 1. The Czech Republic with the position of the Příbram-Jince Basin (A), distribution of Cambrian rocks of the Jince Formation in the Př́ibram-Jince Basin (B), geographic position of discussed localities (C), stratigraphic ranges of Condylopyge in the Jince Formation of the Příbram-Jince Basin (D).

1. foot of the slope known as Vinice near Jince (locality 15 in Fatka and Kordule 1992); lowermost levels of the Acadolenus snajdri Zone sensu Fatka and Szabad (2014).

2. locality Potůček near Rejkovice (= locality 12 in Fatka and Kordule 1992); lower levels of the Paradoxides (Eccaparadoxides) pusillus Zone sensu Fatka and Szabad (2014). Specimens CGS CW 17 and CGS FK 63.

3. foot of the slope known as Vinice near Jince (locality 20 in Fatka and Kordule 1992); lower levels of the Onymagnostus hybridus Biozone sensu Fatka and Szabad (2014). Specimen CGS CW 18.

several other agnostids such as Phalagnostus nudus, Pleuroctenium granulatum granulatum, Skryjagnostus pompeckji, Peronopsis div. sp., Phalacroma bibullatum, Diplorrhina triplicata and is usually associated with remains of paradoxidid, conocoryphid and solenopleurid trilobites, cinctan echinoderms and hyoliths (see Prantl 1947, Fatka 2005).

In the Př́bram-Jince Basin, the presence of Condylopyge was published for the first time by Fatka and Kordule (1992, p. 50). Later, Valíček and Szabad (2002, pl. 1, fig. 1) figured the internal mould of a quite small isolated cephalon collected from the oldest faunal association of the Jince Formation at the foot of the slope known as Vinice near Jince (Text-fig. 1). These authors classified this specimen as Condylopyge rex but without any discussion.

Fatka et al. (2004, tab. 3) revised the stratigraphical ranges of taxa established in the Jince Formation, including agnostids. The occurrence of Condylopyge cf. rex was reported from the lower stratigraphical levels of the Eccaparadoxides pusillus Zone as well as from the oldest layers of the Onymagnostus hybridus Zone.

\section{Repository}

Figured specimens from the Jince Formation of the Prríbram-Jince Basin are housed in the collections of the Czech Geological Survey, Prague (inventory numbers CGS CW 17, CW 19 and FK 63, Text-fig. 2a-2c respectively). For comparison figured specimens from the Skryje-Týrovice Basins are housed in the collections of the Palaeontological Department of the National Museum, Prague (inventory numbers NM-L43011a, NM-L43014 and NM-L43013, Text-fig. $2 \mathrm{~d}-2 \mathrm{f}$ respectively). 

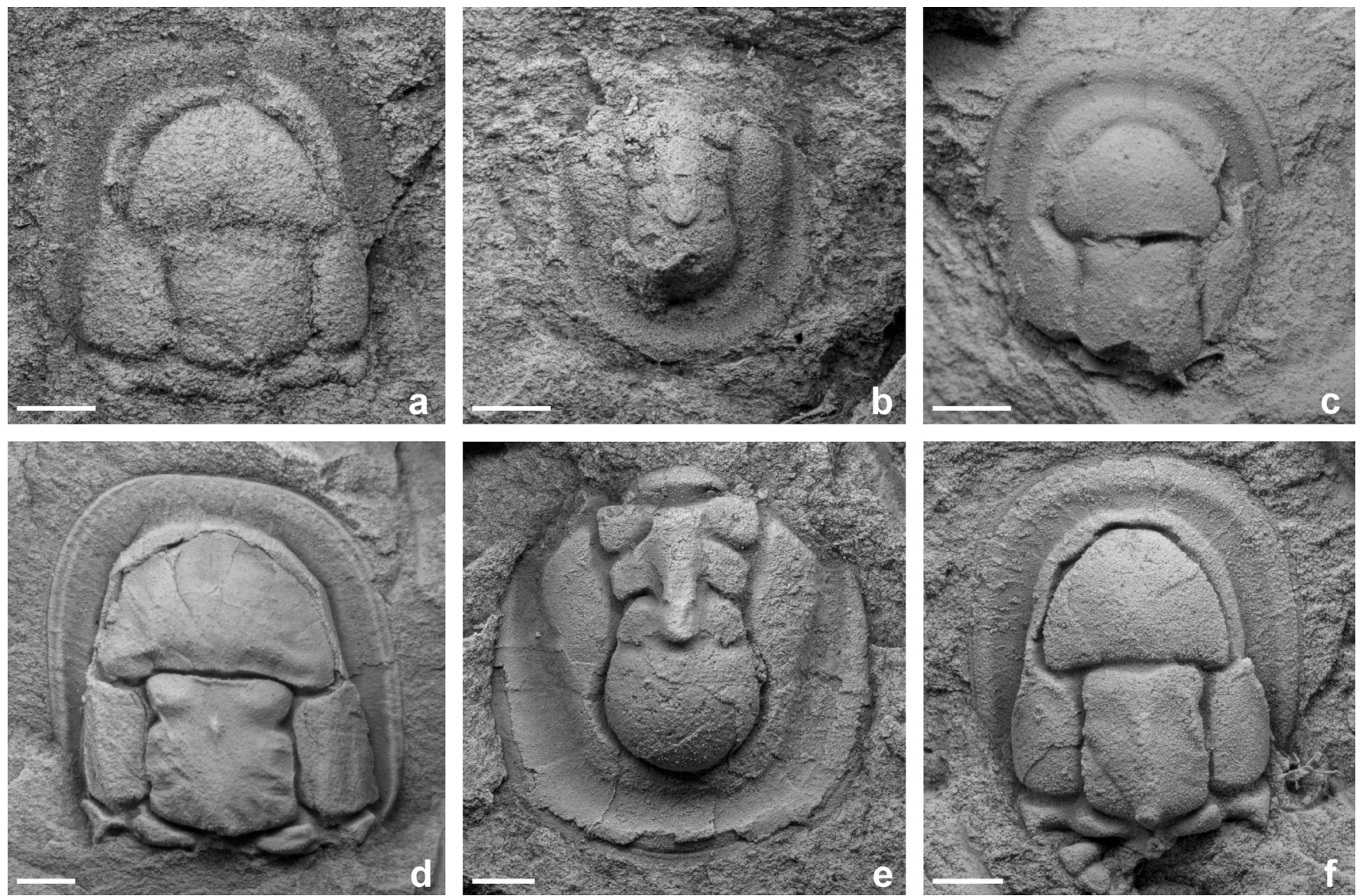

Text-fig. 2. Condylopyge cf. rex (BARRAnde, 1846), middle Cambrian, latest Cambrian Stage 5 and lower Drumian, Jince Formation, Př́bram-Jince Basin.

a. internal mould of isolated cephalon (Specimen CGS CW 17), Potůček near Rejkovice locality (= locality 12 in Fatka and Kordule 1992) in lower levels of the Paradoxides (Eccaparadoxides) pusillus Zone.

b. latex cast of external mould of isolated pygidium (Specimen CGS FK 63), Potůček near Rejkovice locality (= locality 12 in Fatka and Kordule 1992) in lower levels of the Paradoxides (Eccaparadoxides) pusillus Zone.

c. internal mould of isolated cephalon (Specimen CGS CW 18), foot of the slope known as Vinice near Jince (locality 20 in Fatka and Kordule 1992) in lower levels of the Onymagnostus hybridus Zone.

Condylopyge rex (BARRAnde, 1846), middle Cambrian, lower Drumian, Buchava Formation, Paradoxides (Eccaparadoxides) pusillus Zone, Skryje-Týřovice Basin.

d. internal mould of isolated cephalon (NM-L43011a), Karáskovská rokle - nad chatami.

e. internal mould of isolated pygidium (NM-L43014), Lủmek u Týřovic.

f. internal mould of isolated cephalon (NM-L43013), Lůmek u Týřovic.

Whitened with ammonium chloride sublimate. All scale bars are $1 \mathrm{~mm}$. Photographs by Martin Valent (National Museum Prague).

\section{Systematic palaeontology}

Phylum Arthropoda von SIEBOLD, 1848 Order Agnostida SALTER, 1864

Suborder Agnostina SALTER, 1864

Superfamily Condylopygoidea RAYMOND, 1913

Family Condylopygidae RAYMOND, 1913

R e m a r ks. Like numerous earlier authors, we follow Kobayashi (1962) in recognizing the Condylopygoidea at the level of superfamily, while the family concept is that of Raymond (1913). Condylopygoidea differs from Agnostoidea M'Coy, 1849 by (1) the characteristic expansion of the anterior glabellar lobe, (2) the apparent presence of occipital structures instead of basal lobes, (3) the presence of three anterior segments in an otherwise axiolobate pygidium, and (4) the supposed retention of a cephalothoracic aperture (see Rushton 1979, p. 45). Condylopygoidea are therefore the most distinctive members of the Agnostina (see Shergold et al. 1990, Shergold and Laurie 1997).

\section{Genus Condylopyge Hawle et CoRDa, 1847}

Ty p e species: Battus rex Barrande, 1846, p. 17; middle Cambrian, Drumian, Paradoxides (Eccaparadoxides) pusillus Zone, Buchava Formation, Skryje-Týřovice Basin, Barrandian area, the Czech Republic.

D i a g n o s is . See Shergold and Laurie (1997, p. 383).

D i s c u s s i o n. The type species was briefly described by Barrande (1846, p. 17) as Battus Rex. In the following year, Hawle and Corda (1847, p. 50, tab. 3, fig. 24) provided a German diagnosis of their new genus Condylopyge, which was based on morphology of the only one known specimen. 
At the end of the $19^{\text {th }}$ century, three other species and one subspecies were described, namely Agnostus cambriensis Hicks, 1871; Agnostus regius SJÖGREN, 1872; Agnostus regulus MATTHEW, 1886 and Agnostus rex var. transectus MatTheW, 1896.

The study by Hawle and Corda (1847) was repeatedly cited by Jaekel (1909, p. 380), but this author did not mention the genus Condylopyge and surprisingly established a new genus Paragnostus with type species Agnostus rex. This approach was rejected by Raymond (1913, p. 138) and all subsequent authors with the argument that the same species is the type of Condylopyge HaWle et CORDA, 1847. Condylopyge was briefly discussed by Kobayashi (1939, p. 107, table), who listed six species and two subspecies, all ranging from the early to mid middle Cambrian. Shergold et al. (1990, p. 57) and Shergold and Laurie (1997, p. 383) give the stratigraphic range of Condylopyge from the Protolenus Zone of Avalonia to the Ptychagnostus punctuosus Zone of Baltica.

Hitherto sixteen species are assigned to Condylopyge:

Condylopyge amitina Rushton, 1966, Purley Shale, Britain;

Condylopyge antiqua Elicki et PILOLla, 2004, Campo Pisano Formation, Sardinia, Italy;

Condylopyge cambrensis (HICKs, 1871), Newgale Formation, Wales, Britain;

Condylopyge carinata WeStergård, 1936, Alum Shale Formation, Sweden and Chamberlains Brook Formation, Newfoundland, Canada;

Condylopyge carinata vicina EgOrova in SAVITSKIY et al., 1972, Siberian Platform, Russia;

Condylopyge cruzensis Liñán et Gozalo, 1986, Valdemiedes Formation, Spain and Tröbitz Formation, Germany;

Condylopyge eli GeYer, 1998, Jbel Wawrmast Formation, Morrocco;

Condylopyge globosa (ILling, 1916), Abbey Shales, Britain;

Condylopyge imperator Howell, 1935, Couloma Formation, France;

Condylopyge matutina DEAn, 2005, Çal Tepe Formation, Turkey;

Condylopyge regia (SJöGREN, 1872), Alum Shale Formation, Sweden;

Condylopyge rex (BARRANDE, 1846), Buchava Formation,

Barrandian area, Czech Republic;

Condylopyge regulus (MATTHEw, 1886), Handford Brook Formation, Massachusets, the U.S.A;

Condylopyge spinigera WeStergård, 1946, Alum Shale Formation, Sweden and possibly also Chamberlains Brook Formation, Newfoundland, Canada;

Condylopyge transectus (MATTHEw, 1896), Chamberlain's Brook Formation, Massachusets, U.S.A.

Nomina nuda

Condylopyge ishensis PERF. (ex Korzhev 2012);

Condylopyge etaerus in FLETCHER, 1972.

\section{Condylopyge cf. rex (BARRANDE, 1846)}

\author{
Text-fig. $2 \mathrm{a}-\mathrm{c}$
}

1992 Condylopyge cf. rex; Fatka and Korule, p. 50.

2004 Condylopyge cf. rex; Fatka et al., p. 377.

Material and locality. The internal mould of a broken cephalon (CGS CW 17, Text-fig. 2a) and an external mould of a pygidium (CGS FK 63, Text-fig. 2b), preserved in purple-brown fine greywacke. Both specimens were collected at the locality Potůček near Rejkovice (= locality 12 in Fatka and Kordule 1992) in lower levels of the Paradoxides (Eccaparadoxides) pusillus Zone sensu Fatka and Szabad (2014).

The internal mould of a cephalon (CGS CW 18, Text-fig. $2 \mathrm{c}$ ) preserved in green-grey mudstone and collected by one of the authors (V.K.) from the man-made excavation at the foot of the slope known as Vinice near Jince (locality 20 in Fatka and Kordule 1992) in lower levels of the Onymagnostus hybridus Zone sensu Fatka and Szabad (2014).

$\mathrm{D}$ e s c r i p t i o n. Cephalon roughly rectangular, gently rounded in front with slightly medially flattened surface. Postero-lateral sides slightly diverging. Axis convex, well vaulted, reaching about 80 percent of the total cephalic length and more than half the cephalon width. Anteroglabella triangular in outline with rounded anterior and postero-lateral margins, sagittal length of anteroglabella about three-quarters of the width. Posteroglabella slightly longer (sag.) than wide (tr.), reaching slightly more than two-thirds the width of the anteroglabella. A small median tubercle developed in the centre of the posteroglabella, a more massive spine is present at the posterior end of the posteroglabella. Border furrow relatively wide, shallow, border moderately wide.

Pygidium without marginal spines, slightly longer than wide. The convex border of uniform width, anteriorly narrower. The axis long with an expanded rounded posterior lobe. Axis bears a distinct elongated keel ending at the posterior lobe. F1 and F2 orientated forward, F3 bent slightly backward.

Thoracic segments unknown.

D i s c u s s i o n. The lectotype of Condylopyge rex was selected by Šnajdr (1958, p. 52) from Barrande's original collection housed in the National Museum Prague (coll. Barrande ČC 237, No. 1034, NM-L16556), and was figured by Barrande (1852, pl. 49, fig. 5a, b), Šnajdr (1958, pl. 2, fig. 1), Horný and Bastl (1970, pl. 1, fig. 2), Shergold et al. (1990, fig. 19.2) and Shergold and Laurie (1997, fig. 240.3).

For comparison, three specimens of Condylopyge rex from the Skryje-Týřovice Basin are presented here (Text-fig. $2 \mathrm{~d}-2 \mathrm{f}$ ). The $C$. cf. rex pygidium is morphologically identical to that of the type species (compare Text-fig. 2b and 2e). Morphology of both cephala from the Jince Formation of the Príbram-Jince Basin agree with topotype specimens of $C$. rex from the Buchava Formation of the Skryje-Týřrovice Basin. However, the median tubercle is situated in the middle of the posteroglabella, while in specimens of C. rex from the Skryje-Týřovice Basin this tubercle is located more anteriorly (compare Text-fig. 2a and $2 \mathrm{c}$ with $2 \mathrm{~d}$ and $2 \mathrm{f}$ ). This morphological feature excludes a definitive assignment to the type species. 
D i s tribution. Condylopyge rex (BARRANDE, 1846) was originally described from the "Pod hruškou" locality near Týřovice (Šnajdr 1958, Fatka 2005). It is one of the abundant agnostids occurring in the higher stratigraphical levels of the Buchava Formation in the Skryje-Týrovice Basin of the Barrandian area (Šnajdr 1958, Fatka 2005). This large agnostid has subsequently been found in Baltica, Avalonia and several areas in West Gondwana.

Baltica. C. rex has been reported from southern Sweden (Tullberg 1880, Westergård 1946, Ahlberg et al. 2009, Weidner and Nielsen 2014), the Oslo area of Norway (Høyberget and Bruton 2008) and from Pleistocene erratic boulders of northern Germany (Rudolph 1990, 1994, Buchholz 2004).

Avalonia. C. rex has been known from Britain (Illing 1916, Rushton 1979, Rees et al. 2013) and from south-eastern Newfoundland (Howell 1925, Hutchinson 1962, Fletcher 2007).

West Gondwana. This agnostid species is documented from areas assigned to the Armorican Terrain Assemblage, namely in the Iberian Chains of Spain (Sdzuy 1961, Liñan and Gozalo 1986, Chirivella et al. 2009, Gozalo et al. 2011), in Montagne Noire of France (Courtesolle 1973, Álvaro et al. 1998), and in the Franconian Forest and Leipzig area of Germany (Elicki 1997, Sdzuy 2000, Elicki and Geyer in Heuse et al. 2010, Geyer 2010).

\section{Condylopyge sp.}

2002 Condylopyge rex (BARRANDE, 1846); Valíček and Szabad, p. 75-76, pl. 1, fig. 1.

Material and locality. Internal moulds of two cephalic shields preserved in fine yellow decalcified concretion. These specimens have not been housed to date in an official collection. They allegedly come from the foot of the slope known as Vinice near Jince (locality 15 in Fatka and Kordule 1992) in the lowermost levels of the Acadolenus snajdri Zone sensu Fatka and Szabad (2014).

R e marks. A description of these two specimens was not published by Valíček and Szabad (2002). The one small figure of a cephalon does not provide sufficient information for species determination. Consequently, determination of the species is not followed and classification in open nomenclature is preferred for this poorly documented and inaccessible material.

\section{Conclusions}

The exoskeleton of the cephalic shield does not show morphological characters decisive for determination of species in Condylopyge; reliable species assignment should be based on morphology of both pygidial and cephalic shields. Rare and poorly preserved specimens are to be left in open nomenclature. Consequently, the oldest cephalic shields of agnostids established in the Jince Formation are determined as Condylopyge sp., rare specimens established in higher stratigraphical levels are classified as Condylopyge cf. rex.

\section{Acknowledgements}

We thank Jan Ove Ebbestad (Uppsala University, Sweden) and Petr Budil (Czech Geological Survey Prague, Czech Republic) for their helpful review and the linguistic improvements.

Jan Wagner (National Museum Prague) is acknowledged for his kind editorial help. This research was supported by Prvouk P44 of the Ministry of Education, Youth and Sports of the Czech Republic. Martin Valent (National Museum Prague) is acknowledged for access to specimens held in the collections of the National Museum Prague and for help with photography.

\section{References}

Álvaro, J. J., Courjault-Radé, P., Chauvel, J. J., Dabard, M. P., Debrenne, F., Feist, R., Pillola, G. J., Vennin, E., Vizcaïno, D. (1998): New Cambrian stratigraphic framework of the Pardailhan and Minervois nappes (southern Montagne Noire). - Géologie de la France, 2: 3-12.

Ahlberg, P., Axheimer, N., Babcock, L. E., Eriksson, M. E., Schmitz, B., Terfelt, F. (2009): Cambrian high-resolution biostratigraphy and carbon isotope chemostratigraphy in Scania, Sweden: first record of the SPICE and DICE excursions in Scandinavia. - Lethaia, 42(1): 2-16. http://dx.doi.org/10.1111/j.1502-3931.2008.00127.x

Barrande, J. (1846): Notice préliminaire sur le Système Silurien et les trilobites de Bohême. - C. L. Hirschfeld, Leipsic, vi+97 pp.

Barrande, J. (1852): Système Silurien du Centre de la Bohême, lère Partie, Crustacès, Trilobites. 2 vols. - Chez l'auteur et éditeur, Prague, Paris, 935 pp. +51 pls. http://dx.doi.org/10.5962/bhl.title.14776

Barrande, J. (1872): Système Silurien du Centre de la Bohême, Supplément au vol. 1. Trilobites, crustacés divers et poissons. - Chez l'auteur et éditeur, Prague, Paris, 647 pp.

Beyrich, E. (1845): Über einige böhmische Trilobiten. G. Reimer, Berlin, $47 \mathrm{pp}$.

Buchholz, A. (2004): Ein Geschiebe der Hypagnostus parvifrons-Zone (Mittelkambrium B3) mit feinstratigraphischer Schichtung und seltenen sowie neuen Trilobiten. - Archiv für Geschiebekunde, 3(8/12): 501-524.

Bruthansová, J., Fatka, O., Budil, P., Král, J. (2007): 200 years of trilobite research in the Czech Republic. - In: Mikulic, M. G., Landing, E., Kluessendorf, J. (eds), Fabulous fossils -300 years of worldwide research on trilobites. New York State Museum Bulletin, 507: 51-80.

Chirivella, J. B., Dies Álvarez, M. E., Gozalo, R., Liñan, E. (2009): Los Agnostina (Trilobita) del piso 5 del Cámbrico (Leoniense-Caesaraugustiense inferior) de las Cadenas Ibéricas (NE de España). - In: Palmquist, P., PérezClaros, J. A. (eds), Comunicaciones de las XXV Jornadas de la Sociedad Española de Paleontología, Universidad de Málaga, Málaga, p. 155-159.

Courtesolle, R. (1973): Le Cambrien de la Montagne Noire. Biostratigraphie. - Laboratoire de Géologie CEARN de la Faculté des Sciences de Toulouse, Toulouse, 241 pp. 
Dean, W. T. (2005): Trilobites from the Çal Tepe Formation (Cambrian), Near Seydişehir, Central Taurides, Southwestern Turkey. - Turkish Journal of Earth Sciences, 14: $1-71$.

Elicki, O. (1997): Biostratigraphic data of the German Cambrian - present state of knowledge. - Freiberger Forschungshefte, C 466(4): 155-165.

Elicki, O., Pilolla, G. L. (2004): Cambrian microfauna and palaeoecology of the Campo Pisano Formation at Gutturu Pala (Inglesiente, SW Sardinia, Italy). - Bolletino della Societá Paleontologica Italiana, 43: 383-401.

Fatka, O. (2005): Association of fossils and history of research at the Týřovice - "Pod hruškou" locality (Middle Cambrian, Skryje-Týřrovice Basin, Barrandian area). Journal of the Czech Geological Society, 49(3-4): 107-117.

Fatka, O., Kordule, V. (1992): New fossil sites in the Jince Formation (Middle Cambrian, Bohemia). - Věstník Českého geologického ústavu, 67(1): 47-60.

Fatka, O., Kordule, V., Szabad, M. (2004): Stratigraphic distribution of Cambrian fossils in the Příbram-Jince Basin (Barrandian area, Czech Republic). - Senckenbergiana lethaea, 84(1/2): 369-384.

Fatka, O., Szabad, M. (2014): Biostratigraphy of Cambrian in the Př́bram-Jince Basin (Barrandian area, Czech Republic). - Bulletin of Geosciences, 89(2): 413-429. http://dx.doi.org/10.3140/bull.geosci.1456

Fletcher, T. P. (2007): Correlating the zones of "Paradoxides hicksii" and "Paradoxides davidis" in Cambrian Series 3. - Memoirs of the Association of Australasian Palaeontologists, 33: 35-56.

Geyer, G. (1998): Intercontinental, trilobite-based correlation of the Moroccan early Middle Cambrian. - Canadian Journal of Earth Sciences, 35(4): 374-401. http://dx.doi.org/10.1139/e97-127

Geyer, G. (2010): Cambrian and lowermost Ordovician of the Franconian Forest. - In: Fatka, O., Budil, P. (eds), The 15th Field Conference of the Cambrian Stage Subdivision Working Group, Czech Geological Survey, Prague, p. $78-89$.

Gozalo, R., Chirivella Martorell, J. B., Esteve, J., Liñan, E. (2011): Correlation between the base of Drumian Stage and the base of middle Caesaraugustan Stage in the Iberian Chains (NE Spain). - Bulletin of Geosciences, 86(3): 545-554.

http://dx.doi.org/10.3140/bull.geosci.1254

Hawle, I., Corda, A. J. C. (1847): Prodrom einer Monographie der böhmischen Trilobiten. - Abhandlungen der Königlichen Böhmischen Gesellschaft der Wissenschaften, Prague, 5(5): 117-292.

Heuse, T., Blumenstengel, H., Elicki, O., Geyer, G., Hansch, W., Maletz, J., Sarmiento, G. N., Weyer, D. (2010): Biostratigraphy - The faunal province of the southern margin of the Rheic Ocean. - In: Linnemann, U., Romer, R. L. (eds), Pre-Mesozoic Geology of Saxo-Thuringia - From the Cadomian Active Margin to the Variscan Orogen, Schweizerbart, Stuttgart, p. $99-170$.

Hicks, H. (1871): Description of new species of fossils from the Longmynd rocks of St. David's. - Quarterly Journal of the Geological Society of London, 27: 399-404.
Høyberget, M., Bruton, D. L. (2008): Middle Cambrian trilobites of the suborders Agnostina and Eodiscina from the Oslo Region, Norway. - Palaeontographica, Abteilung A, 286: 1-87.

Howell, B. F. (1925): The faunas of the Cambrian Paradoxides beds at Manuels, Newfoundland. - Bulletins of American Paleontology, 11: 1-140.

Howell, B. F. (1935): Cambrian and Ordovician Trilobites from Hérault, Southern France. - Journal of Paleontology, 9(3): 222-238.

Horný, R., Bastl, F. (1970): Type specimens of fossils in the National Museum Prague, I. Trilobita. - National Museum, Prague, 356 pp.

Hutchinson, R. D. (1962): Cambrian stratigraphy and trilobite faunas of southeastern Newfoundland. Bulletin, Geological Survey of Canada, 88: 1-156 . http://dx.doi.org/10.4095/123902

Illing, V. C. (1916): The Paradoxidian fauna of a part of the Stockingford Shales. - Quarterly Journal of the Geological Society of London, 71(for 1915): 386-450.

Jaekel, O. (1909): Über die Agnostiden. - Zeitschrift der Deutschen geologischen Gesellschaft, 61: 380-401.

Kobayashi, T. (1939): On the Agnostids (Part 1). - Journal of the Faculty of Science, Imperial University of Tokyo, Section II, 5(5): 69-198.

Kobayashi, T. (1962): The Cambro-Ordovician formations and faunas of South Korea, Part IX. Palaeontology VIII, The Machari fauna. - Journal of the Faculty of Science, University of Tokyo, 14(1): 1-152.

Liñan, E., Gozalo, R. (1986): Trilobites del Cámbrico inferior y medio de Murero (Cordillera Ibérica). - Memorias del Museo Paleontológico de la Universidad de Zaragoza, 2: $1-104$.

Matthew, G. F. (1886): Illustrations of the fauna of the St. John Group continued. III. - Descriptions of new genera and species, (including a description of a new species of Solenopleura by J. F. Whiteaves). - Transactions of the Royal Society of Canada, 3(4): 29-84.

Matthew, G. F. (1896): Faunas of the Paradoxides beds in eastern North America, No 1. - Transactions of the New York Academy of Sciences, 15: 192-247.

M'Coy, F. (1849): On the classification of some British fossil Crustacea with notices of some new forms in the University collection at Cambridge. - Annals and Magazine of Natural History, Series 2, 4: 161-179, 330-335, 392-414.

Prantl, F. (1947): O nalezišti zkamenělin Pod hruškou v skryjsko-týřovickém kambria [On the Pod Hruškou“ locality in the Skryje-Týřovice Cambrian]. - Věstník Musejního spolku královského města Rakovníka a politického okresu rakovnického, 32: 53-58. (in Czech)

Raymond, P. E. (1913): Some changes in the names of genera of trilobites. - The Ottawa Naturalist, 26: 137-142.

Rees, A. J., Thomas, A. T., Lewis, M., Hughes, H. E., Turner, P. (2014): Overview and biostratigraphy. - In: Rees, A. J., Thomas, A. T., Lewis, M., Hughes, H. E., Turner, P. (eds), The Cambrian of SW Wales: Towards a United Avalonian Stratigraphy. Memoirs, Geological Society, London, 42: $1-30$.

http://dx.doi.org/10.1144/M42.1 
Rudolph, F. (1990): Bestimmungshilfe für Gescheibesammler. 9. Die Gattung Condylopyge Hawle et Corda, 1847. - Geschiebekunde aktuell, 6(2): 69-71.

Rudolph, F. (1994): Die Trilobiten der mittelkambrischen Geschiebe. - Verlag F. Rudolph, Wankendorf, 309 pp.

Rushton, A. W. A. (1966): The Cambrian trilobites from the Purley Shales of Warwickshire. - Monograph of the Palaeontographical Society, London, 120(511): 1-55.

Rushton, A. W. A. (1979): A review of the Middle Cambrian Agnostida from the Abbey Shales, England. - Alcheringa, 3(1): 43-61. http://dx.doi.org/10.1080/03115517908565439

Salter, J. W. (1864): On some new fossils from the Lingula-Flags of Wales. - Quarterly Journal of the Geological Society of London, 20: 233-241. http://dx.doi.org/10.1144/gsl.jgs.1864.020.01-02.33

Savitskiy, V. E., Evtushchenko, V. M., Egorova, L. I., Kontorovich, A. E., Shabanov, Y. Y. (eds) (1972): Kembriy Sibirskoy platformy (Yudoma-Olenekskiy tip razreza. Kuonamskiy kompleks otlozheniy) [Cambrian of the Siberian platform (Judomian-Olenetsky type section, Kuonamsky Complex deposits)]. - Trudy Sibirskiy nauchno-issledovatel'skiy Institut geologii, geofiziki i mineral'nogo syr'ya (SNIIGGiMS), 130: 1-199. (in Russian)

Schlotheim, E. F. von (1823): Nachträge zur Petrefactenkunde. Abth. 2. - Becker'schen Buchhandlung, Gotha, $114 \mathrm{pp}$.

Sdzuy, K. (1961): Das Kambrium Spaniens. Teil II: Trilobiten. - Abhandlungen, Akademie der Wissenschaften und der Literatur, Mathematisch-Naturwissenschaftlichen Klasse, 1961(7-8): 499-690.

Sdzuy, K. (2000): Das Kambrium des Frankenwaldes. 3. Die Lippertsgrüner Schichten und ihre Fauna. - Senckenbergiana lethaea, 79(2): 301-327. http://dx.doi.org/10.1007/bf03043644

Shergold, J. H., Laurie, J. R. (1997): Suborder Agnostina Salter, 1864. - In: Kaesler, R. L. (ed.), Treatise on Invertebrate Paleontology, Part O, Arthropoda 1,
Trilobita, Revised, Geological Society of America and University of Kansas, Boulder (Colorado) and Lawrence (Kansas), p. 331-383.

Shergold, J. H., Laurie, J. R., Sun Xiaowen (1990): Classification and review of the trilobite order Agnostida Salter, 1864: an Australian perspective. - Report, Bureau of Mineral Resources, Geology and Geophysics, 296: $1-93$.

Sjögren, A. (1872). Om några försteningar i Ölands Kambriska lager. - Geologiska Föreningens i Stockholm Förhandlingar, 1: 67-80. (in Swedish) http://dx.doi.org/10.1080/11035897209443816

Šnajdr, M. (1958): Trilobiti českého stř̌edního kambria [The trilobites of the Middle Cambrian of Bohemia]. Rozpravy Ústředního ústavu geologického, 24: 1-280. (in Czech with English summary)

Tullberg, S. A. (1880): Om Agnostus-arterna i de Kambriska aflagringarne vid Andrarum. - Sveriges Geologiska Undersökning C, 42: 1-37. (in Swedish)

Valíček, J. (2006): A new agnostid trilobite from the SkryjeTýřovice area (Middle Cambrian, Jince Formation, Barrandian area, Czech Republic). - Palaeontologia Bohemiae, 10: 43-46.

Valíček, J., Szabad, M. (2002): Revision early Middle Cambrian trilobite fauna from Central Bohemia. Paleontologia Bohemiae, 7(2): 75-98.

Weidner, T., Nielsen, A. T. (2014): A highly diverse trilobite fauna with Avalonian affinities from the Middle Cambrian Acidusus atavus Zone (Drumian Stage) of Bornholm, Denmark. - Journal of Systematic Palaeontology, 12(1): 23-92. http://dx.doi.org/10.1080/14772019.2012.740080

Westergård, A. H. (1936): Paradoxides oelandicus beds of Öland. - Sveriges Geologiska Undersökning C, 394: $1-66$.

Westergård, A. H. (1946): Agnostidea of the Middle Cambrian of Sweden. - Sveriges Geologiska Undersökning C, 477: 1-140. 